\title{
Y. OYAMA,M.D.: ON THE AUDIOMETRIC TEST FINDINGS OF THE SAW-MILL WORKERS
}

\section{製材作業員の聴力像について}

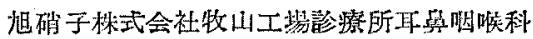

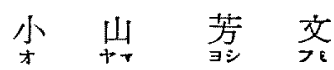

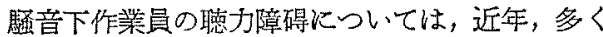
論ぜられる所となつたが，就中，㱔䌯，打鋲を始め， 坑内作業，通信員等の聴力像に関しては，幾多報告 され，殊に河田氏は，音響外甥として広く検討さ れ，その受傷性，聴賞疲労現象等に就いて言及さ れ，更に原田氏は，騷音の聴器に及涪す影響につい

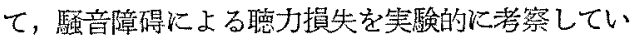
る。著者は少数乍ら，余り省みられなからた製材作

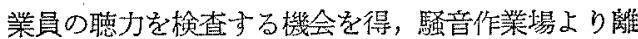
れた後の，一定時間の聴力像の变動について興味を 持ち，その結果を得たので報告し，大方の御批判を 仰ざたいと思 5 。

\section{I． 製材作業の騒晋測定}

測定には，英弘精機製指示騷音計を用い，佋和 29 年 7 月 16 日文び同年 12 月 30 日の 2 回測定し た。測定位置は作業位置と発生源との中央に打いて 発生源の方向に Receiver 向け，製材作業の中央 部，印刷機，動力带銛，丸鋸，横鋸の影響を 10 力 所につき测定したが，平均 70〜103phone の結果 を得た。これらの機找は，午前 8 時 30 分より午前 4 時 30 分迄，午前午後各 1 回及び正个に休止する 外は，絶兄ず運行し緼けている。

\section{II. 聴力楂查}

検查は昭和 30 年 1 月より，同年 3 月造行い，無

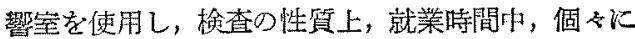
実施した。

1) 検查刘象

北九州某工場に於て，上記㗪音下にて作業中の作 業貣 12 名を選んだ．年命は27才より50才运．経 験年数は現在作業以就業して，1 年4 カ月より16 年 3 刃月である。個人の既往歴，過去に扣ける治療の 有無, 耳鼻咽喉科領域現症, 家族歴, 之の他, 頭部
外賃，爆発音，中毒，赀好等について詳細を調查し た。

2)検查方法

就業途中にて，作業より品倠れた直後，検查を行い その 10 分後, 再検査文びその検查後 10 分後, 再検 查，都合 3 回に亘り，永島製 49-B-Audiometer により測定し, 反対側を TY49-A 雑音発生器にて 遮蔽し，気敦及び骨尊を測定し，正常德力にて補正 し得た Audiogram により聴力損失，聴力百分率， 聴力損失率, Fowler の力法等の成績について検討 した。

\section{III. 検查成綪}

1) 難聴程度

戸塚，岡本氏の分類の如く，言語聴力を最も忠実 飞表わすと思われる C8 (1024)，C4 (2048) Kつい て，12名 24 耳を検查各回江亘り分類したが，平均 次の如き結果を得た。

\begin{tabular}{|c|c|c|c|}
\hline & $\mathrm{C}^{3}$ & $\mathrm{C}^{4}$ & \\
\hline 両耳軽度難聴 & 30db 以内 & $35 \mathrm{db}$ 以内 & 6 \\
\hline 両耳中等妄難聴 & 30 70db 上内 & $35 \sim 60 \mathrm{db}$ & \\
\hline 右軽度左小等度 & & & \\
\hline 難＼cjkstart鲶 & & & \\
\hline 両耳高度難聴 & $70 \mathrm{db}$ 以上 & 60db 以上 & \\
\hline
\end{tabular}
となった。

\section{2) Audiogram 聴力型}

河田氏の Audiogram 聴力型により分類すれば， 作業より離れた直後の聴力型は水平型最も多く，6 人 11 耳に於てみられ，その中 A・B 型（珠に $A_{1}$ と $\mathrm{B}_{\mathbf{1}}$ との閒) が多く，次いで $\mathrm{B}$ 型（殊に $\mathrm{B}_{\mathbf{1}}$ と $B_{2}$ との閒)， $A$ 型 $\left(A_{2}\right.$ と $A_{3}$ との間)が見られた (表 1,2 ).

急降型 (C 型) 5 人 9 耳飞認められ，その中 3 
表 1

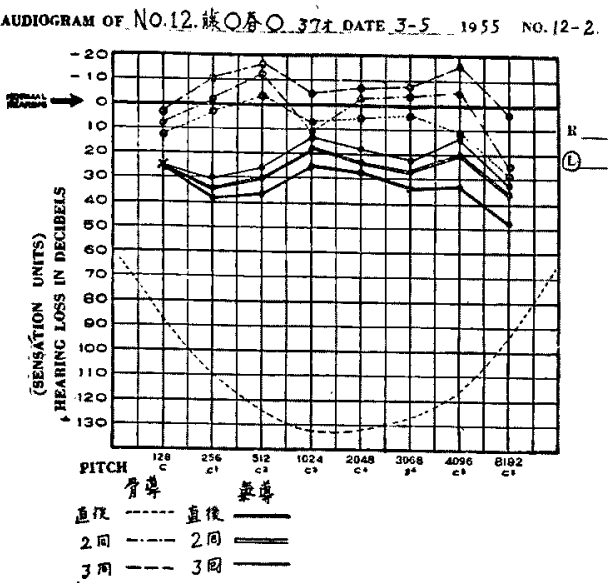

表 2

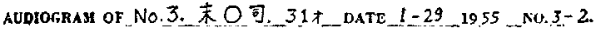

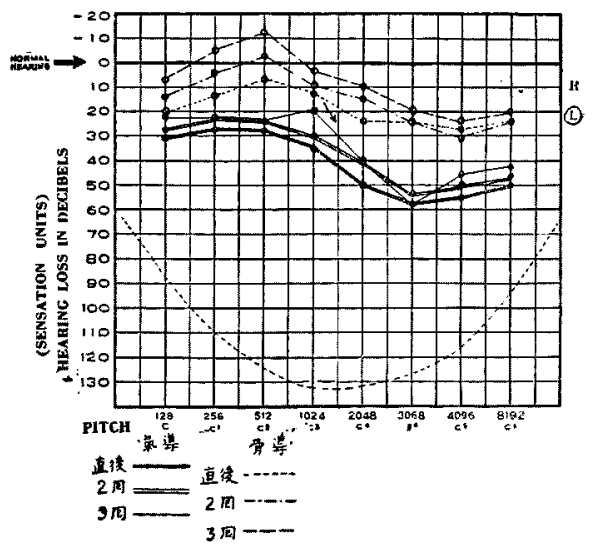

人 6 耳は $\mathrm{C}^{3}$ より下降を示し，その小，例10は $\mathrm{C}^{5}$ に於て完全に損失をみた。例 4 は右耳で $\mathrm{G}^{\mathbf{4}}$ に，左 耳て G4に下降が認められた（表了）。

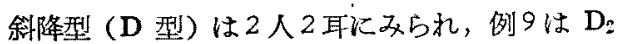
と $\mathrm{D}_{3}$ との間にあり，例几は $\mathrm{C}^{5}$ に於て dip 党見 た. 凹型 ( $\mathrm{F}$ 型) 類似型は例9右耳にみられ $\mathrm{F}_{2}$ を 示し，それも第 2 回検查即 10 分後には $A$ と $A_{3}$ と の間を示す水平型となつている、W 型類似型は例1 右耳儿見られ $W_{1}$ と $W_{2}$ との間に見られた。然し 之等作業より離れた直後の聴力損失も，その倦 10 分後，又次の10 分後に於ては前迹した $\mathrm{F}$ 型 (例9)
表 3

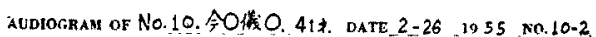

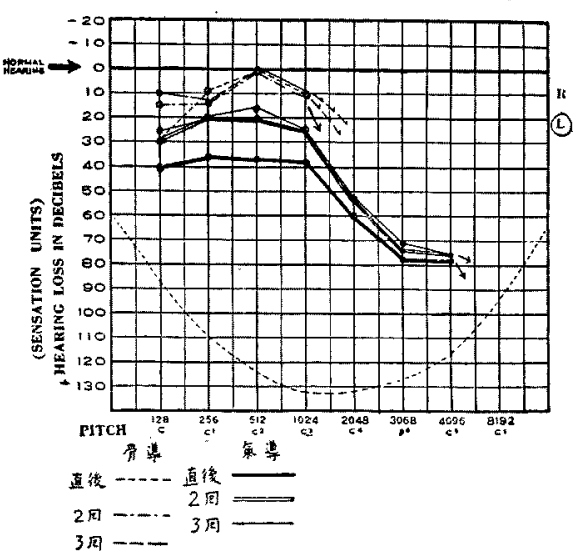

を除いてはや」平均した曲線が得られたが，C～C 3 の間は稣力損失少なくなり，その籍は 3〜 $5 \mathrm{db}$ 程度 であつた。

然し乍ら, 急降型, 斜降型を示するのは $\mathrm{C}^{3}$ 以上 の高音域では殆んど変化は認められなかつた。

3) 各回検查成續の变化について

各人 C (128) 〜 $\mathrm{C}^{6}$ (8192)の8 種類の波長に於て， 聴力椇失及び聴力百分率，聴力損失率を算定した が，去の結果は，作業から傩れた後は概して低調音 $\mathrm{C} \sim \mathrm{C}^{3}$ の閪に比較的上刑が認められ，各回 $3 \sim 5 \mathrm{db}$ の聴力上昇が諗められた，台高調音については，大 部分著しい变化はなかつた。 $\mathrm{C}^{5} \operatorname{dip}$ と明らかに判 定出来るのは 2 名 3 耳であつた，各人に於て各回 8 種類の波長による暴なつた聴力損失

$\mathrm{X}=\frac{\mathrm{C}^{2}+\mathrm{C}^{3}+2 \times \mathrm{C}^{4}}{4}$ 及び゙ Fowler の方法を選び, これを算定して検討した（䒧 4,5 ).

即言語聴力百分率を測定，言語の聴取心最必

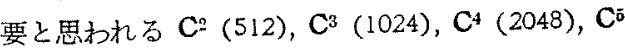
(4096)の4周波数を取り上げ，各回測定した各耳 の気，骨導聴力䦪值を補正し，15db 㕛はそれ以上 の骨導聴力損失ある場合は Recruitment 係数にて 気莩聴力損失を䋠正し，算定し得た各田各回の数值 を比較分類した．即，各回を通じ，漸次聴力損失曲 線が上昇したと見做されるるのを $\mathrm{A}$ 群とし，初回 に比し 2 回目は上昇，3回目は再び下降したという 
表 4 德力摃失徘 $\mathrm{X}=\frac{\mathrm{C}_{2}+\mathrm{C}_{3} \times 2+\mathrm{C}_{4}}{4}$

\begin{tabular}{|c|c|c|c|c|}
\hline 被桧者 NO. & 耳 & 離湦直传 & 20 分流 & 40 分復 \\
\hline \multirow[b]{2}{*}{1} & 店 & 32.5 & 29.5 & 27.5 \\
\hline & 左 & 38.0 & 30.5 & 26.5 \\
\hline \multirow[b]{2}{*}{2} & 后 & 30.0 & 25.5 & 23.0 \\
\hline & $t_{s}$ & 22.3 & 22.0 & 21.4 \\
\hline \multirow{2}{*}{3} & 后 & 35.0 & 17.0 & 20.3 \\
\hline & F & 31.0 & 31.3 & 26.3 \\
\hline \multirow{2}{*}{4} & $\frac{1}{t}$ & 23.3 & 22.5 & 22.0 \\
\hline & 左 & 28.5 & 21.5 & 2.0 .5 \\
\hline \multirow{2}{*}{5} & 后 & 22.5 & 22.0 & 20.8 \\
\hline & F & 24.5 & 21.5 & 21.0 \\
\hline \multirow{2}{*}{6} & 石 & 21.5 & 20.0 & 19.0 \\
\hline & 庑 & 27.3 & 24.0 & 22.5 \\
\hline \multirow[b]{2}{*}{7} & to & 35.8 & 32.0 & 23.5 \\
\hline & F & 31.0 & 30.3 & 23.5 \\
\hline \multirow[b]{2}{*}{8} & to & 49.0 & 40.3 & 38.3 \\
\hline & I & 48.0 & 40.8 & 35.8 \\
\hline \multirow[b]{2}{*}{9} & 5 & 56.8 & 22.5 & 20.3 \\
\hline & 左 & 54.0 & 26.5 & 23.0 \\
\hline \multirow{2}{*}{10} & 5 & 23.8 & 29.0 & 22.4 \\
\hline & F. & 42.5 & 31.5 & 26.0 \\
\hline \multirow[b]{2}{*}{11} & $\pi$ & 23.0 & 22.0 & 20.5 \\
\hline & t & 34.0 & 30.3 & 21.8 \\
\hline \multirow{2}{*}{12} & to & 20.3 & 14.3 & 12.0 \\
\hline & 左 & 26.3 & 22.5 & 20.5 \\
\hline
\end{tabular}

表 5 言䇎聴力百分萃 (Percentage of Capacity to heary $\mathrm{v}$ Speech)

Fowler 9方法 $\frac{\mathrm{C}_{2} \times 15+\mathrm{C}_{3} \times 30+\mathrm{C}_{4} \times 40+\mathrm{C}_{5} \times 15}{100}$ $15,30,40,15$ は補正你数

\begin{tabular}{|c|c|c|c|c|}
\hline 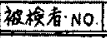 & 耳 & 隺場直後 & 20分後 & 40分後 \\
\hline \multirow[b]{2}{*}{1} & ta & 35.65 & 33.95 & 32.33 \\
\hline & 左 & 43.20 & 35.60 & 35.43 \\
\hline \multirow[b]{2}{*}{2} & 后 & 29.50 & 25.30 & 25.10 \\
\hline & 厌 & 24.85 & 23.50 & 22.98 \\
\hline \multirow[b]{2}{*}{3} & 后 & 38.65 & 19.00 & 25.50 \\
\hline & 左 & 31.85 & 33.80 & 32.50 \\
\hline \multirow[b]{2}{*}{4} & t & $2^{6} .95$ & 26.70 & 27.00 \\
\hline & F. & 38.85 & 29.10 & 29.25 \\
\hline \multirow{2}{*}{5} & $\frac{5}{5}$ & 25.00 & 23.75 & 21.70 \\
\hline & 厓 & 26.95 & 27.00 & 23.20 \\
\hline \multirow{2}{*}{6} & 店 & 23.40 & 19.75 & 18.32 \\
\hline & 左 & 30.60 & 27.90 & 24.98 \\
\hline \multirow[b]{2}{*}{$?$} & 后 & 38.85 & 34.75 & 31.15 \\
\hline & 左 & 36.35 & 38.40 & 31.60 \\
\hline \multirow{2}{*}{8} & 右 & 42.85 & 42.45 & 39.30 \\
\hline & 左 & 47.60 & 41.25 & 38.25 \\
\hline \multirow{2}{*}{9} & to & 59.55 & 25.35 & 23.43 \\
\hline & $\sqrt{2}$ & 59.85 & 30.70 & 21.70 \\
\hline \multirow[t]{2}{*}{10} & 㕆 & 36.95 & 38.35 & 35.40 \\
\hline & 厓 & 54.95 & 47.05 & 33.70 \\
\hline \multirow[t]{2}{*}{11} & 右 & 27.05 & 24.30 & 23.40 \\
\hline & 左 & 37.90 & 34.40 & 36.35 \\
\hline \multirow[t]{2}{*}{12} & $\frac{\sqrt{D}}{E}$ & 22.50 & 17.55 & 15.10 \\
\hline & 左 & 31. & 20.80 & \\
\hline
\end{tabular}

如き不安定なるのを B 群とし，各回を通して

$\begin{array}{ll}\text { 両耳共上昇したるの } & 6 \text { 名 } \\ \text { 一耳上犁, 反対耳不定 } & 4 \text { 名 } \\ \text { 両耳共不定 } & 2 \text { 名 }\end{array}$

といら結果を得た. Fowler に上る言語聴力百分率 を以て算定して得た分類と, 年令, 経験年数, 耳科 所見との関係は，表6の通りである.

\begin{tabular}{|c|c|c|c|c|c|}
\hline 群 & 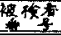 & 倒耳 & 年令 & 程端年数 & 耳科所罗 \\
\hline \multirow{10}{*}{$A$ 群 } & 1 & $\sqrt{\sqrt{4}}$ & 39 & 12 年 & 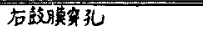 \\
\hline & 2 & 両 & 31 & 5 年 & \\
\hline & 5 & 右 & 40 & 1年45月 & 最中隔左弯曲症 \\
\hline & 6 & 甪 & 48 & 3年34月 & \\
\hline & 7 & 右 & 50 & 8年 & 方鼓䐜第化 \\
\hline & 8 & 而 & 42 & 2年2ナ月 & 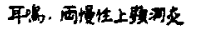 \\
\hline & 9 & 两 & 36 & 2年34月 & \\
\hline & 10 & 左 & 41 & 5年8ー月 & \\
\hline & 1 & 右 & 27 & 4年 & \\
\hline & 12 & 雨 & 37 & 4年64月 & 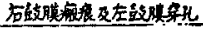 \\
\hline \multirow{5}{*}{ B群 } & 3 & $\overline{\text { 雨 }}$ & 32 & 37647 & \\
\hline & 4 & 而 & 46 & 16年3+月 & \\
\hline & 5 & 左 & & & \\
\hline & 7 & 左 & & & \\
\hline & 10 & 右 & & & \\
\hline
\end{tabular}

これによれば鼓膜に軽度の所見が認められたにる 拘らず，作業を離れてからの聴力損失曲線が，比較 的よく上舁したものがあつた。

\section{IV. 総括及び結䠉}

著者は 70 103phone の平均せる騒音下に 特け る動力鋁による製材作業員 12 名について，作業現 場上り離れた㨁後及びその検查後 10 分, 又その検 查後10分の夫ょ 3 回の聴力検查により得た Audiogram 飞より考察した。

（1）被検者は不就業時に一応聴力検查に㹂熟さ せ，各人良好な部分でも10db 程度の聴力損失を示 し, 各人 2 回の予備検查では，測定值の偏差も $1 \mathrm{db}$ 程度であつた。被榆者 12 名は軽度, 9名中等度, 3 名，右軽度，左中等度 2 名，高度 1 名の難聴度を示 し，この離場直後の聴力に比し，第 3 回検查に和い ても聴力損失 $10 \mathrm{db}$ 以上上昇をみたものはなかつた。 気尊聴力閔值の変化は必ずしも全波長に亘つて上昇 するものではなく C〜C $\mathrm{C}^{3}$ の間に平均 3〜5db の聴 力損失曲線の上昇がみられたが，然し作ら各回検查 に括ける聴力損失の上昇は，検查それ自身対する 
被検者の慣れ，局所及び全身的疲学度等，その他の 条件が加味されねばならず，加うるに測定值の標準 偏差も考慮すべきで，一定の結論に達する事は不可 能々考光る。

（2）Audiogram 恥力型飞ついては河辺，永田両 氏は造船工場还業員の聴力像は，水平型及びそれ飞 $\mathrm{C}^{5}$ dip を伴な5 60 $42 \%$ ，斜降型 $33 \%$ ，急降型 20 \%と述べており，坂口氏は製䑾工にあつては $\mathrm{C}^{\mathbf{j}} \mathrm{dip}$ 及びその類似曲線 30\%で，斜降型 $16.9 \%$ であり， 堀進夫は $\mathrm{C}^{5}$ dip 及びその 類似曲線 24\%で，勤務 年数の增加と共に次第に上り低音及び高音域が障碍

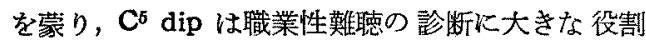
を有すると述べている. 更に小関氏は，電報局促業 員飞 C゚ dip が詰められたと報告している.著者の 成樍では水平型が50\%飞見られ $\mathrm{C}^{3}, \mathrm{C}^{4} \mathrm{G}^{4}, \mathrm{C}^{5}$ K ては下降が見られ，斜降型は 2 例 2 耳に見られた。 完全な C' dip は2名 3 耳飞認められた。何急降型 及び䣄降型を示するのにあっては, 検查各回の聴力 損失の変化は $\mathbf{C}^{3} よ り$ 高調音では殆んどみられなか つた.

(3) 年令と各回検查に於汸る㯖力損失の上舁率と は，特に関保は想められなかつた。

（4）経験年数については，別表泟示与如く，経験 年数少ない者必ずしも良好でなく，これは年令と経 業年数と比例していないので一定した傾向は認めら れなかつた。これについてては草川氏は，造船所従業 員について，聴力障碍の程度は必ずしも彷業年数に 比例せず，窑乃騒音の筫, 強さ, 持続時間等の他, 内耳の被障碍型とでも言うべき因子を列挙してい る.

(5) 局所々見との関係は, 小関氏は電報局従業員 は, 受信側耳の槌管把柄部血管拡張を見ると述べ， 坂口氏炭礦学務者の鼓膜に陥入と溷濁とが見ら
れ，伝音采障㥂にも関心を持つベしと強調してい る. 著者の成績では，局所々見のあるむのは，䆝万 A 群即聴力損失曲線の上昇の良好な例炕多く見ら れ，例 12 の如く，右鼓膜症痕，左鼓膜紫孔あるに 拘らず，画耳共聴力上昇を見て和り，例7の如く， 鼓膜穿孔ある右耳の聴力が上昇し，所見なき左耳の 方が不定である等の結果が得られ一定していない。 又自覚症状としては，作業後の聴覚疲学感の訴之は 比較的少ない，又上記対策としては，耳栓を施して いる。

以上平均せる騷音下飞抬いて動力鋸による製材作 業員の聴力像について，時間的に測定，観祭し，2， 3の知見を得たので報告した。

\section{主 要 文 献}

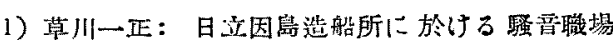

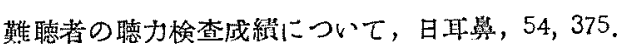

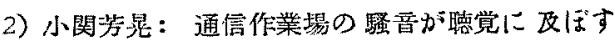
影㬚，（第 1 報）通信彷業貝の耳悬咽喉科的検查成

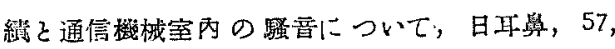
935. 3) 河辺㩘孝, 永田実：職業性難聴の Audiogram, 日聑學, 57, 106. 4) 原田筑紫: 騒曋 の㯖器障碍に関する研焪, 日耳耳學, $57,260.5$ )

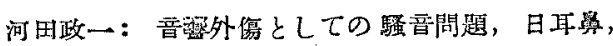

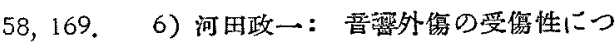

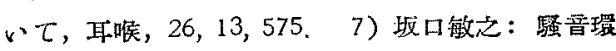
境孷坑学務者のオージオグラムに就、て，耳㘈， $25,7,324.8 ）$ 立木鹠：聴賞検查法前庭迷路機 能検查法.99)竹㐫和头：音双聴力検查法の㭘

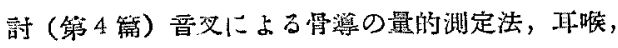
$28,7,475$.

（原驐到着二昭和 318 -28 日） 